\title{
The Bitter Taste Receptor Agonist Quinine Reduces Calorie Intake and Increases the Postprandial Release of Cholecystokinin in Healthy Subjects
}

\author{
Paolo Andreozzi, ${ }^{1}$ Giovanni Sarnelli, ${ }^{1}$ Marcella Pesce, ${ }^{1}$ Francesco P Zito, ${ }^{1}$ Alessandra D'Alessandro, ${ }^{1}$ Viviana Verlezza, ${ }^{1}$ \\ Ilaria Palumbo, ${ }^{1}$ Fabio Turco, ${ }^{1}$ Katherine Esposito, ${ }^{2}$ and Rosario Cuomo ${ }^{1 *}$ \\ ${ }^{1}$ Department of Clinical Medicine and Surgery, “Federico II" University, Naples, Italy; and ${ }^{2}$ Department of Clinical and Experimental Medicine, \\ Second University of Naples, Italy
}

\begin{abstract}
Background/Aims
Bitter taste receptors are expressed throughout the digestive tract. Data on animals have suggested these receptors are involved in the gut hormone release, but no data are available in humans. Our aim is to assess whether bitter agonists influence food intake and gut hormone release in healthy subjects.
\end{abstract}

\section{Methods}

Twenty healthy volunteers were enrolled in a double-blind cross-over study. On 2 different days, each subject randomly received an acid-resistant capsule containing either placebo or $18 \mathrm{mg}$ of hydrochloride $(\mathrm{HCl})$ quinine. After 60 minutes, all subjects were allowed to eat an ad libitum meal until satiated. Plasma samples were obtained during the experiment in order to evaluate cholecystokinin (CCK) and ghrelin levels. Each subject was screened to determine phenylthiocarbamide (PTC) tasting status.

\section{Results}

Calorie intake was significantly lower when subjects received $\mathrm{HCl}$ quinine than placebo $(514 \pm 248$ vs $596 \pm 286 \mathrm{kcal} ; P=$ 0.007). Significantly higher CCK $\Delta T_{90}$ vs $T_{0}$ and $\Delta T_{90}$ vs $T_{60}$ were found when subjects received $\mathrm{HCl}$ quinine than placebo $(0.70$ \pm 0.69 vs $0.10 \pm 0.86 \mathrm{ng} / \mathrm{mL}, P=0.026 ; 0.92 \pm 0.75$ vs $0.50 \pm 0.55 \mathrm{ng} / \mathrm{mL}, P=0.033$, respectively). PTC tasters ingested a significantly lower amount of calories when they received $\mathrm{HCl}$ quinine compared to placebo (526 \pm 275 vs $659 \pm 320 \mathrm{kcal}$; $P=0.005)$, whereas no significant differences were found for PTC non-tasters (499 \pm 227 vs $519 \pm 231 \mathrm{kcal} ; P=0.525)$.

Received: February 18, 2015 Revised: April 20, 2015 Accepted: April 21, 2015

(c) This is an Open Access article distributed under the terms of the Creative Commons Attribution Non-Commercial License (http://creativecommons. org/licenses/by-nc/4.0) which permits unrestricted non-commercial use, distribution, and reproduction in any medium, provided the original work is properly cited.

${ }^{*}$ Correspondence: Rosario Cuomo, MD

Department of Clinical Medicine and Surgery, Federico II University Hospital School of Medicine, Via S. Pansini 5, Building 6, 80131 Napoli, Italy

Tel: +39-081-7463892, E-mail: rcuomo@unina.it

Financial support: None.

Conflicts of interest: None.

Author contributions: Study concept and design: Paolo Andreozzi, Giovanni Sarnelli, and Rosario Cuomo; Subject enrollment and acquisition of data: Paolo Andreozzi, Giovanni Sarnelli, Marcella Pesce, Francesco P Zito, Alessandra D'Alessandro, Viviana Verlezza; Biochemical analysis: Ilaria Palumbo and Fabio Turco; Analysis and interpretation of data: Katherine Esposito, Paolo Andreozzi, Giovanni Sarnelli, and Rosario Cuomo; and Drafting of the manuscript: Paolo Andreozzi, Giovanni Sarnelli, and Rosario Cuomo.

ORCID: Paolo Andreozzi, http://orcid.org/0000-0002-4604-0126; Giovanni Sarnelli, http://orcid.org/0000-0002-1467-1134; Marcella Pesce, http://orcid.org/0000-0001-5996-4259; Francesco Paolo Zito, http://orcid.org/0000-0002-1084-3373; Viviana Verlezza, http://orcid.org/0000-0001-9569-2369; Ilaria Palumbo, http://orcid.org/0000-0003-0387-1461; Fabio Turco, http://orcid.org/0000-0001-9149-3872; Katherine Esposito, http://orcid.org/0000-0002-3652-5154; Rosario Cuomo, http://orcid.org/0000-0003-0768-8381. 


\section{Conclusions}

This study showed that intra-duodenal release of a bitter compound is able to significantly affect calorie intake and CCK release after a standardized meal. Our results suggest that bitter taste receptor signaling may have a crucial role in the control of food intake.

(J Neurogastroenterol Motil 2015;21:511-519)

\section{Key Words}

Cholecystokinin; Food intake; Ghrelin; Quinine; Taste

\section{Introduction}

Taste is a complex sensory modality involved in the detection of food quality. It is commonly accepted that the so-called "basic" tastes (ie, bitter, sweet, umami, sour, and salty) have been naturally selected to facilitate nutrient consumption and help avoid the ingestion of potentially harmful foods. ${ }^{1}$ For instance, the sweet taste is perceived as palatable and is classically associated with energy-dense foods, whereas the bitter taste is innately aversive and related to toxic compounds.

The mechanisms underlying taste detection in the oral cavity have been well established; in fact, tastants are recognized by a number of receptors, including ion channels (salty and sour) and G protein-coupled receptors (GPCRs) (bitter, sweet, and umami). ${ }^{1}$ Specifically, the GPCR type 1 taste receptor family (T1R) comprises 3 different subunits that heterodimerize to detect sweet $(\mathrm{T} 1 \mathrm{R} 2+\mathrm{T} 1 \mathrm{R} 3)$ and umami (T1R1 + T1R3) tastants, while the type 2 taste receptor (T2R) family is responsive to bitter compounds. ${ }^{2,3}$ The ability to taste bitter compounds varies greatly among individuals. The best-known example of this variability is the genetic ability to taste phenylthiocarbamide (PTC) and 6-N propylthiouracil (PROP). Based on the ability to recognize PTC or PROP, individuals can be defined as "tasters" or "non-tasters." ${ }^{4}$

In the last decade, several studies have demonstrated the expression of taste receptors and their downstream signaling molecules in the gut, leading to the hypothesis that gastrointestinal taste system may play a role in the gut chemosensitivity. ${ }^{5,6}$ In particular, studies in model cell lines ${ }^{7,8}$ and a histochemical study ${ }^{9}$ have shown that $\mathrm{T} 2 \mathrm{R}$ family members are expressed by entero-endocrine cells (EECs), which constitute a first level of integration of the information coming from the lumen. ${ }^{10}$ EECs in the gastrointestinal (GI) tract play a crucial role in the control of food intake through several ways. Their activation results in the release of a large array of GI peptides, such as glucagon-like peptide 1 (GLP-1), cholecystokinin (CCK) and ghrelin, ${ }^{11}$ all involved in the control of food intake. Ghrelin, released by gastric EECs, is the only known orexigenic gut peptide and its plasma levels increase during fasting and rapidly fall after the meal. ${ }^{12,13}$ Other hormones, such as CCK, GLP 1, and peptide YY (PYY), exert an opposite effect, thus inhibiting food intake. CCK is the anorexigenic peptide that has been more thoroughly studied ${ }^{14}$; this hormone is released by I-cells into the duodenum in response to intra-luminal lipids and proteins. ${ }^{15,16}$ The CCK inhibitory effects on food intake are thought to be mediated via CCK1 receptors on vagal afferents. ${ }^{17}$

A previous study has shown that the stimulation of $\mathrm{T} 2 \mathrm{R}$ with bitter compounds induced the release of the anorexigenic hormone CCK from mouse EEC lines. ${ }^{18}$ Moreover, the intragastric gavage of bitter compounds induced the release of ghrelin in mice. ${ }^{19}$ However, this evidence derives from experiments carried out in vitro or on animals, but no study has translated these findings to in vivo human models to define the role of the stimulation of these receptors on food intake.

In the wake of these results, we hypothesized that bitter taste receptors in the gut could be involved in the control of food intake. Our study thus aimed to investigate the effect of intra-luminal release of a bitter compound ( $\mathrm{HCl}$ quinine) on food intake and gut hormone release in healthy subjects.

\section{Materials and Methods}

\section{Participants}

Twenty healthy adult volunteers ( 12 women, 8 men; median age 27 years) were recruited from the personnel and students of the Federico II University Medical School. Their mean \pm SD body mass index (BMI) was $24 \pm 4 \mathrm{~kg} / \mathrm{m}^{2}$. Exclusion criteria were: prior abdominal surgery - except for appendectomy, pos- 
itive history of organic or functional GI diseases, use of medications able to affect GI motility and binge eating disorders. Informed written consent was obtained from all the participants and the study was approved by the Ethics Committee of the Federico II University of Naples.

\section{Study Protocol}

This was a randomized, double blind, placebo-controlled, cross-over study. Following an overnight fast, approximately at 11:30 AM, all subjects underwent ad libitum test 60 minutes after they randomly received a capsule containing placebo or $18 \mathrm{mg}$ of hydrochloride $(\mathrm{HCl})$ quinine (Sigma-Aldrich; Gillingham, UK). After 1 week, the subjects repeated the same experiment receiving a capsule containing $\mathrm{HCl}$ quinine or placebo, respectively (Fig. 1A). Randomization was assured by a computer-generated random list (MS Excel 2007). The experimental dose was chosen after a preliminary study with different amount of $\mathrm{HCl}$ quinine
$(18,36$, and $72 \mathrm{mg})$. Given that no differences were observed in terms of GI feelings and calorie intake among various doses tested, we decided to use the lower dose (data not shown). The capsule was acid-resistant in order to facilitate the release of bitter compound or placebo into the duodenum. Considering the available data on gastric emptying time after an overnight fast, ${ }^{20,21}$ we chose a 60-minute interval between capsule administration and the ad libitum test (see below). During the experiment, a questionnaire was administered to assess GI sensations and plasma samples were obtained in order to evaluate GI peptide levels (Fig. 1B). Afterwards, all subjects were screened to determine PTCtasting status ("tasters" or "non-tasters").

In addition, 8 out of 20 subjects also underwent 2 sessions of breath test for gastric emptying study. A standard meal was served to the subjects 60 minutes after the random administration of a capsule containing $18 \mathrm{mg}$ of $\mathrm{HCl}$ quinine or placebo. Breath samples were collected during the experiments. After 1- week,

A

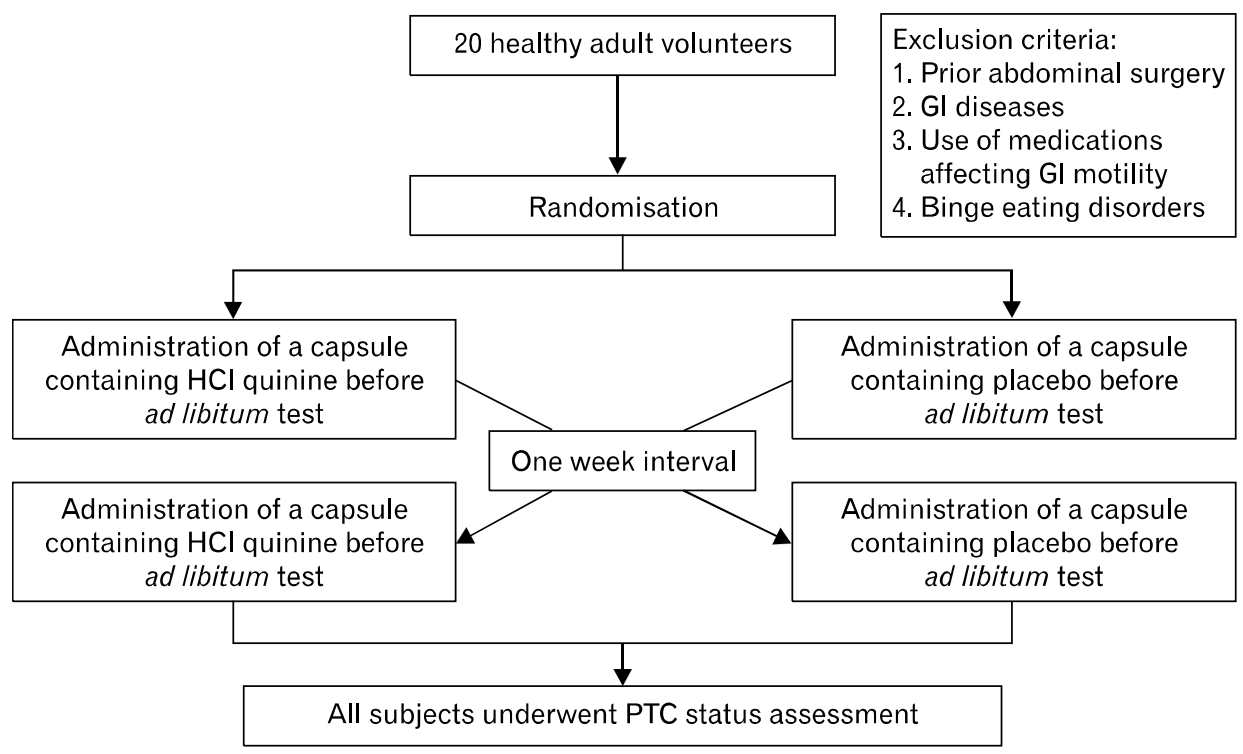

B

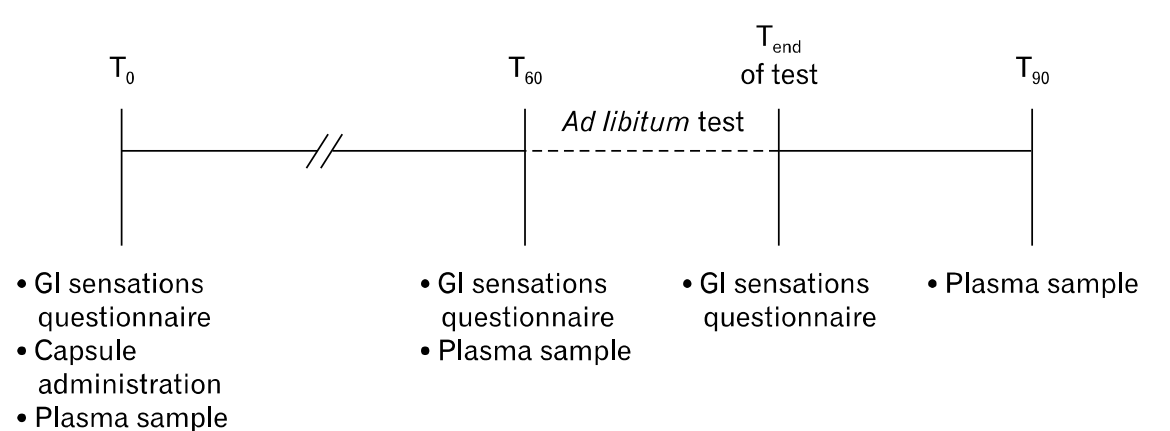

Figure 1. Study design. (A) All subjects randomly received a capsule containing placebo or $18 \mathrm{mg}$ of hydrochloride quinine in a randomized, double blind, cross-over design. (B) The ad libitum test started 60 minutes after capsule administration. Blood samples were taken to assay ghrelin and cholecystokinin at $\mathrm{T}_{0}$, $\mathrm{T}_{60}$, and $\mathrm{T}_{90}$. Gastrointestinal sensation assessment was performed at $\mathrm{T}_{0}, \mathrm{~T}_{60}$, and at the end of ad libitum test $\left(\mathrm{T}_{\text {end }}\right)$. GI, gastrointestinal; $\mathrm{HCl}$, hydrochloride; PTC, phenylthiocarbamide. 
the same subjects repeated the emptying study receiving a capsule containing $\mathrm{HCl}$ quinine or placebo, respectively. Similarly, randomization was assured by the computer generated random list.

\section{Ad libitum Test}

A standardized test was used to assess calorie intake. ${ }^{22} \mathrm{~A}$ standard buffet meal was served 60 minutes after capsule administration. The standard meal was composed of white bread, cheese, and ham spread (Spuntì, Kraft Foods, Italy). The meal was administered by single portions, containing $89 \mathrm{kcal}$ each, until maximum satiety was reached. The composition of single portions was the same: $50 \%$ carbohydrate, $31 \%$ fat, $19 \%$ protein. The food was served in excess to decrease the awareness of food intake. The quantity of food eaten, the volume of water drunk and the meal duration were recorded at the end of the test.

\section{Gastrointestinal Sensations Questionnaire}

GI sensations were evaluated immediately before the administration of the capsule $\left(\underline{T_{0}}\right)$, before beginning of the meal $\left(\underline{T_{60}}\right)$ and at the end of the meal ( $\left.\mathrm{T}_{\text {end }}\right)($ Fig. 1B). GI sensations evaluated included fullness, nausea, bloating, epigastric pain, heartburn, satiety and desire to eat. Measurements were performed by a visual analogue scale (VAS) calibrated to $100 \mathrm{~mm}^{23,24}$

\section{Phenylthiocarbamide Status Assessment}

To determine PTC tasting status we invited all subjects to place, consecutively, 2 paper strips on their tongue: the first one was a control strip, whereas the second one was a strip of filter paper impregnated with $0.3 \mathrm{mg}$ of PTC (Online science mall; Florida, USA). "Tasters" were defined as subjects who perceived the bitter taste when PTC-impregnated blotting paper strip was placed on the tongue. Furthermore, each subject was asked to rate the intensity of their bitter perception of PTC strip on a VAS ranging from $0 \mathrm{~mm}$ (no taste) to $100 \mathrm{~mm}$ (extremely strong taste).

\section{Gastric Emptying Study}

Out of 20 subjects who participated in ad libitum test, 8 (4 women, median age 25 years) underwent a breath test study to determine gastric emptying in a randomized, double blind, placebo-controlled cross-over fashion. Sixty minutes after the administration of $\mathrm{HCl}$ quinine or placebo, they were asked to consume a test meal consisting of $60 \mathrm{~g}$ white bread, $10 \mathrm{~g}$ butter, $50 \mathrm{~g}$ ham, an omelet made from 1 egg with egg yolk charged with $74 \mathrm{kBq}$ ${ }^{13}$ C-octanoic acid (Euriso-top, Saint-Aubin, France) and 100
$\mathrm{mL}$ water. The test meal contained $480 \mathrm{kcal}$ (19\% protein, $53 \%$ carbohydrate, and $31 \%$ fat). Subjects were encouraged to eat the meal within 10 minutes. Breath samples were collected at 15 -minute intervals for 240 minutes postprandially. ${ }^{13} \mathrm{CO}_{2}$-excretion in breath was subsequently analyzed using isotope-selective infrared spectroscopy to derive gastric emptying half-time.

\section{Biochemical Analysis}

Plasma samples were obtained at 0-60-90 minutes after capsules administration, placed in centrifuge tubes containing aprotinin and stored at $-80^{\circ} \mathrm{C}$ immediately after centrifugation. Total plasma immunoreactive ghrelin and CCK were measured by enzyme immunoassay. Ghrelin was measured in duplicate using commercial ELISA kits (Phoenix Pharmaceuticals) ${ }^{25}$; the inter- and intra-assay coefficients of variance were $<10 \%$. The lower and upper detection limits for this assay were $0.12 \mathrm{ng} / \mathrm{mL}$ and $100 \mathrm{ng} / \mathrm{mL}$. CCK (26-33 octapeptide non-sulfated form) was measured in duplicate using a commercial ELISA kit (Phoenix Pharmaceuticals) $^{26}$; the inter- and intra-assay coefficients of variance were $<10 \%$, with a lower detection limit of $0.04 \mathrm{ng} / \mathrm{mL}$.

\section{Sample Size Calculation}

Preliminary data showed a differences of about $100 \mathrm{kcal}$ in terms of calorie intake between the 2 sessions of the study with a standard deviation of differences of $120 \mathrm{kcal}$. Based on this data we calculated that a sample size of at least 13 patients would be required to test our hypothesis with a power of 0.80 and alpha level of 0.05 (PS Power and Sample Size Calculations; Version 3.0).

\section{Statistical Methods}

To evaluate significant differences in terms of GI sensations, a paired $t$ test was used to compare the VAS scores of these parameters in the 2 sessions of the study. The same analysis was performed to evaluate differences in calorie intake, volume of water drunk, meal duration and gastric emptying half-time between the 2 sessions of the experiment, whereas unpaired $t$ test was used to compare difference of calorie intake in the 2 study sessions ( $\Delta$ $\mathrm{Kcal}=\mathrm{Kcal}_{\text {quinine }}-\mathrm{K}_{\text {cal }} \mathrm{l}_{\text {placebo }}$ ) between PTC "tasters" and "non-tasters". Linear regression was used to evaluate the association between bitter PTC intensity and $\Delta \mathrm{Kcal}$.

Hormone profiles were evaluated both in terms of absolute values and as difference of $\mathrm{T}_{90}$ values with $\mathrm{T}_{0}$ (before capsule administration, $\Delta \mathrm{T}_{90} \mathrm{vs} \mathrm{T}_{0}$ ) and $\mathrm{T}_{60}$ values (before test meal, $\Delta \mathrm{T}_{90} \mathrm{vs} \mathrm{T}_{60}$ ). Between 2 sessions, ANOVA with repeated meas- 

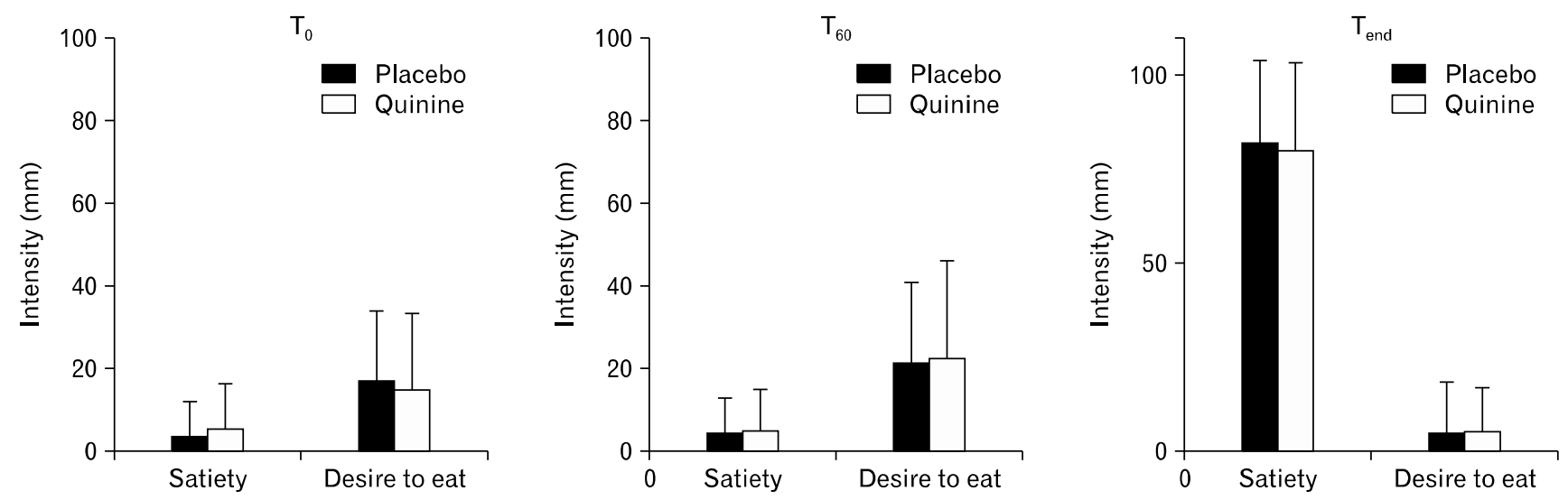

Figure 2. Gastrointestinal sensations in the 2 sessions of the study. No significant differences were observed between 2 experiments in terms of satiety and desire to eat at $\mathrm{T}_{0}, \mathrm{~T}_{60}$, and $\mathrm{T}_{\text {end. }}$.
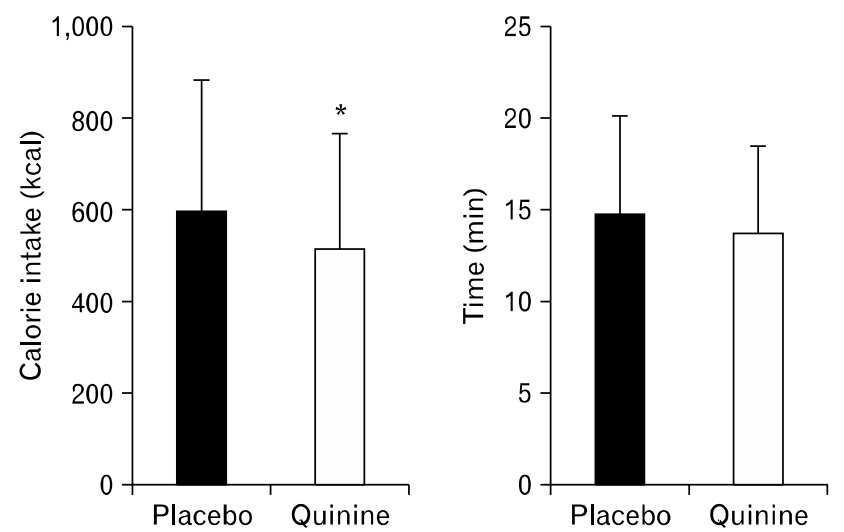

Figure 3. Calorie intake and meal duration in the 2 sessions of the study. Calorie intake was significantly lower when subjects received hydrochloride quinine than placebo $(514 \pm 248$ vs $596 \pm 286 \mathrm{kcal} ; P=$ 0.007). Meal duration did not statistically differ in the 2 sessions of the study. ${ }^{*} P=0.007$.

ures was used to evaluate differences of absolute values, whereas a paired $t$ test was used to compare differences of $\Delta \mathrm{T}_{90} \mathrm{vs} \mathrm{T}_{0}$ and $\Delta \mathrm{T}_{90}$ vs $\mathrm{T}_{60}$ between 2 sessions of the study.

The statistical analysis was performed by the statistical software package SPSS for Windows Version 12.0 (SPSS, Chicago, IL, USA). The results are reported as mean $\pm \mathrm{SD}$. Differences were considered statistically significant when $P$ was $<0.05$.

\section{Results}

\section{Effect of Bitter on Gastrointestinal Sensations}

No subject experienced any oral bitter or unpleasant percep-
Table 1. Ad libitum Test in 20 Subjects After the Administration of $\mathrm{HCl}$ Quinine and Placebo

\begin{tabular}{lccc}
\hline & After $\mathrm{HCl}$ quinine & After placebo & $P$-value \\
\hline Calorie intake (kcal) & $514 \pm 248$ & $596 \pm 286$ & 0.007 \\
Meal duration $(\mathrm{min})$ & $13.7 \pm 4.7$ & $14.7 \pm 5.4$ & 0.403 \\
Water intake $(\mathrm{mL})$ & $157 \pm 57$ & $165 \pm 59$ & 0.186 \\
\hline
\end{tabular}

Data are presented as mean $\pm \mathrm{SD}$.

tion after $\mathrm{HCl}$ quinine or placebo administration, nor were there any adverse reactions after the experiment. No significant differences were observed between the 2 experiments in terms of satiety and desire to eat at $\mathrm{T}_{0}, \mathrm{~T}_{60}$, and $\mathrm{T}_{\text {end }}$ (Fig. 2). No significant differences were found regarding other symptoms or GI sensations (data not shown).

\section{Effect of Bitter on Food Intake}

As shown in Figure 3, subjects ingested a significantly lower amount of calories when receiving the capsule containing $\mathrm{HCl}$ quinine than placebo $(514 \pm 248$ vs $596 \pm 286 \mathrm{kcal} ; P=0.007)$. Conversely, meal duration was not different between the 2 experiments $(13.7 \pm 4.7$ vs $14.7 \pm 5.4$ minutes, $P=0.403)$ (Fig. 3$)$, nor was the amount of water intake different $(157 \pm 57 \mathrm{~mL}$ vs $165 \pm 59 \mathrm{~mL} ; P=0.186)$. All data are showed in Table 1 .

\section{Effect of Bitter on Gut Hormones Release}

There were no significant differences in CCK absolute values when subjects received $\mathrm{HCl}$ quinine or placebo at the different time points $\left(\mathrm{T}_{0}: 1.05 \pm 0.57 \mathrm{vs} 1.50 \pm 1.11 \mathrm{ng} / \mathrm{mL}, P=0.094\right.$; $\mathrm{T}_{60}: 0.82 \pm 0.35 \mathrm{vs} 1.11 \pm 0.79 \mathrm{ng} / \mathrm{mL}, P=0.090 ; \mathrm{T}_{90}: 1.75 \pm$ 0.84 vs $1.60 \pm 1.01 \mathrm{ng} / \mathrm{mL}, P=0.464)$. In order to minimize 
intra-individual variability, we evaluated the difference in CCK with respect to basal values. Significantly higher $\Delta \mathrm{T}_{90} \mathrm{vs} \mathrm{T}_{0}$ and $\Delta \mathrm{T}_{90}$ vs $\mathrm{T}_{60}$ were found when subjects received $\mathrm{HCl}$ quinine compared to placebo $\left(\Delta \mathrm{T}_{90}\right.$ vs $\mathrm{T}_{0}: 0.70 \pm 0.69$ vs $0.10 \pm 0.86$ $\mathrm{ng} / \mathrm{mL}, P=0.033 ; \Delta \mathrm{T}_{90}$ vs $\mathrm{T}_{60}: 0.92 \pm 0.75$ vs $0.50 \pm 0.55$ ng/mL, $P=0.026$ ) (Fig. 4).

On the contrary, ghrelin plasma levels were not significantly different with $\mathrm{HCl}$ quinine or placebo, either when considered as absolute concentrations $\left(\mathrm{T}_{0}: 2.48 \pm 0.66\right.$ vs $2.57 \pm 0.52 \mathrm{ng} / \mathrm{mL}$, $P=0.538 ; \mathrm{T}_{60}: 2.50 \pm 0.48$ vs $2.43 \pm 0.39 \mathrm{ng} / \mathrm{mL}, P=0.493$; $\mathrm{T}_{90}: 2.65 \pm 0.69$ vs $\left.2.45 \pm 0.50 \mathrm{ng} / \mathrm{mL}, P=0.239\right)$ or delta values $\left(\Delta \mathrm{T}_{90}\right.$ vs $\mathrm{T}_{0}: 0.17 \pm 0.62$ vs $-0.13 \pm 0.46 \mathrm{ng} / \mathrm{mL}, P=$ $0.231 ; \Delta \mathrm{T}_{90}$ vs $\mathrm{T}_{60}: 0.15 \pm 0.49$ vs $0.01 \pm 0.37 \mathrm{ng} / \mathrm{mL}, P=$ $0.319)$.

\section{Effect of Bitter on Gastric Emptying Rate}

The evaluation of gastric emptying revealed that in a subset of 8 subjects ( 5 tasters) $\mathrm{HCl}$ quinine was not able to significantly modify the rate of emptying in comparison to placebo $(87 \pm 14$
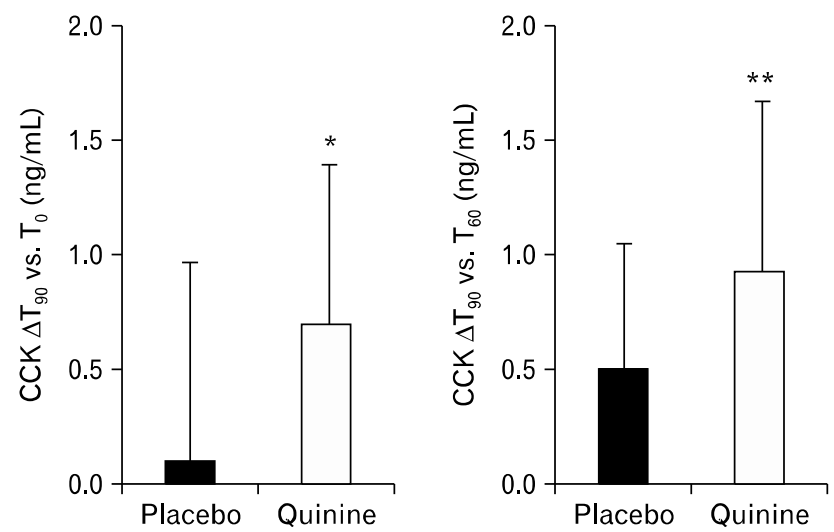

Figure 4. Cholecystokinin (CCK) release after standard meal. Data are expressed as difference vs basal level $\left(\Delta \mathrm{T}_{90}\right.$ vs $\left.\mathrm{T}_{0}\right)$ and vs pre-meal level $\left(\Delta \mathrm{T}_{90} \mathrm{vs} \mathrm{T}_{60}\right)$. Significantly higher $\Delta \mathrm{T}_{90}$ vs $\mathrm{T}_{0}$ and $\Delta \mathrm{T}_{90}$ vs $\mathrm{T}_{60}$ were found when the subjects received a capsule containing hydrochloride quinine vs those taking placebo. ${ }^{*} P=0.033$ and ${ }^{* *} P=0.026$. vs $88 \pm 12$ minutes; $P=0.842$ ).

\section{Phenylthiocarbamide Status Assessment}

According to the PTC paper test, 11 out of 20 subjects were identified as "tasters," while 9 subjects were not able to identify any bitter sensation and were classified as "non-tasters."

Most interestingly, a further analysis revealed that PTC tasters ingested a significantly lower amount of calories when they received $\mathrm{HCl}$ quinine compared to placebo $(526 \pm 275$ vs $659 \pm$ $320 \mathrm{kcal} ; P=0.005)$, whereas no significant differences were found for PTC non-tasters $(499 \pm 227$ vs $519 \pm 231 \mathrm{kcal}$; $P=$ 0.525 ) (Table 2). This finding was even more evident when the difference of calorie intake between the 2 experiments was considered, since PTC tasters presented a significantly different $\Delta$ Kcal compared to non-tasters $(-134 \pm 124$ vs $-20 \pm 89 \mathrm{kcal}$; $P=0.034$ ) (Fig. 5).

Moreover, the linear regression showed a negative association between $\mathrm{PTC}$ bitter intensity and $\Delta \mathrm{Kcal}(r=-0.579 ; P=$ 0.008) (Fig. 6).

Regarding CCK release, in PTC tasters we observed that $\Delta \mathrm{T}_{90}$ vs $\mathrm{T}_{0}$ and $\Delta \mathrm{T}_{90}$ vs $\mathrm{T}_{60}$ after the administration of $\mathrm{HCl}$ quinine was higher compared to placebo but these differences were not statistically significant $\left(\Delta \mathrm{T}_{90}\right.$ vs $\mathrm{T}_{0}: 0.84 \pm 0.72$ vs $0.12 \pm$ $0.88 \mathrm{ng} / \mathrm{mL}, P=0.103 ; \Delta \mathrm{T}_{90}$ vs $\mathrm{T}_{60}: 1.08 \pm 0.88$ vs $0.53 \pm$ $0.57 \mathrm{ng} / \mathrm{mL}, P=0.083)$. Similarly, no significant differences for ghrelin levels were found between the 2 groups in the 2 sessions of the study (data not shown).

\section{Discussion}

The gut "senses" the food, although the molecular mechanisms of GI chemosensitivity are not fully understood. This study showed for the first time that the direct intra-luminal administration of a bitter taste receptor agonist is able to significantly reduce calorie intake in healthy subjects, likely acting on gut bitter taste receptors and altering gut hormone levels.

Table 2. Calorie Intake in Phenylthiocarbamide Tasters and Phenylthiocarbamide Non-tasters After the Administration of $\mathrm{HCl}$ Quinine and Placebo (Number of Subjects)

\begin{tabular}{lccc}
\hline & \multicolumn{2}{c}{ Calorie intake $($ mean $\pm \mathrm{SD}, \mathrm{kcal})$} & $P$-value \\
\cline { 2 - 3 } & After HCl quinine & After placebo & 0.005 \\
PTC tasters $(\mathrm{n}=11)$ & $526 \pm 275$ & $659 \pm 320$ & 0.525 \\
PTC non-tasters $(\mathrm{n}=9)$ & $499 \pm 227$ & $519 \pm 231$ &
\end{tabular}

PTC, phenylthiocarbamide. 

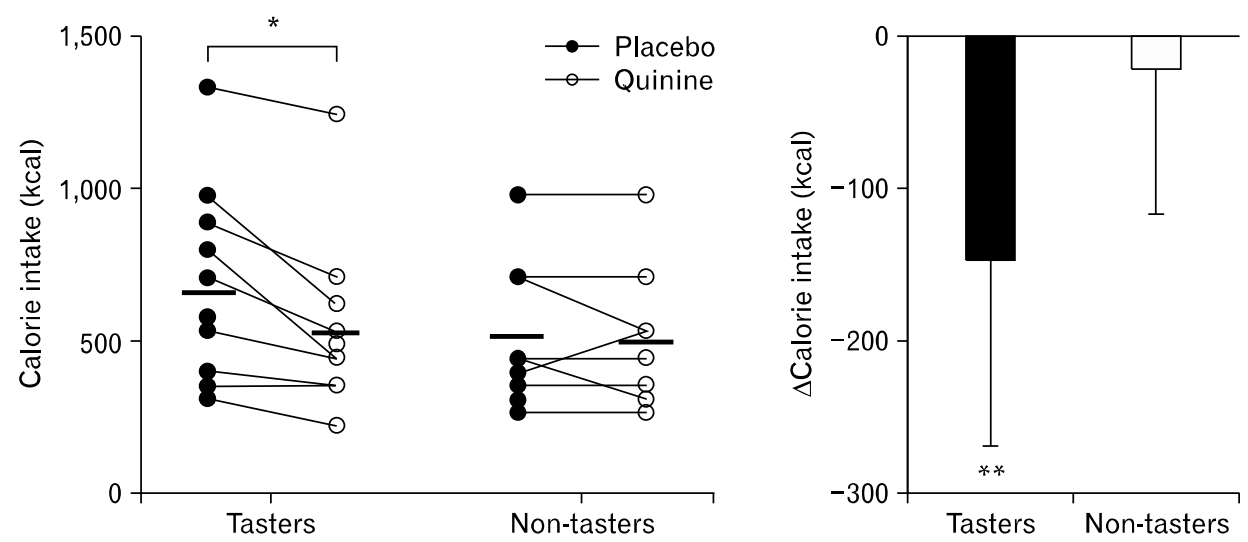

Figure 5. Phenylthiocarbamide (PTC) status assessment. PTC tasters ingested a significantly lower amount of calories when they received hydrochloride quinine compared to placebo $(526 \pm 275$ vs $659 \pm 320 \mathrm{kcal} ; P=0.005)$, whereas no significant differences were found for PTC non-tasters ( $499 \pm 227$ vs $519 \pm 231 \mathrm{kcal} ; P=0.525)$. PTC tasters presented a significantly higher difference in calorie intake between 2 experiments $(\Delta \mathrm{Kcal})$ compared to non-tasters $(-134 \pm 124 \mathrm{vs}-20 \pm 89 \mathrm{kcal} ; P=0.034) .{ }^{*} P=0.005$ and ${ }^{* *} P=0.034$.

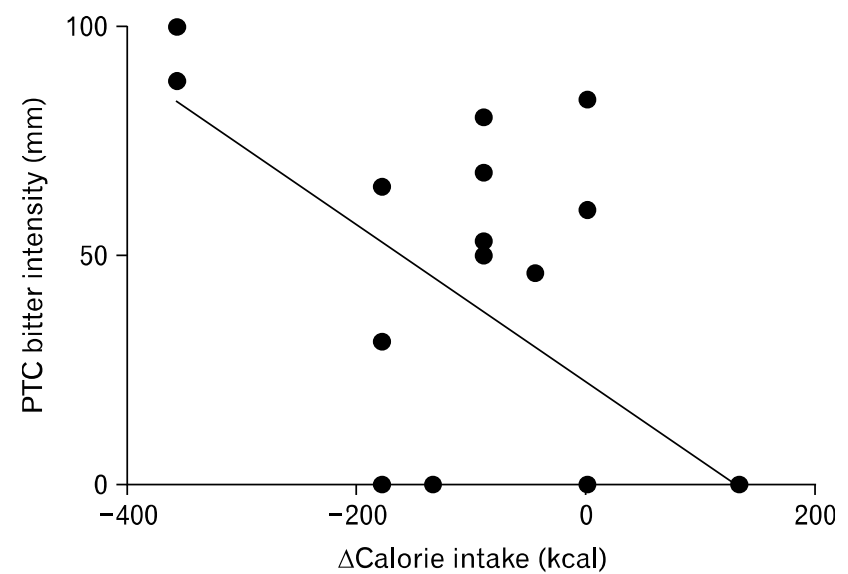

Figure 6. Correlation between bitter phenylthiocarbamide (PTC) intensity and $\Delta \mathrm{Kcal}$ (calorie intake placebo $_{\text {- calorie intake }}$ quinine). Linear regression showed a negative association between $\Delta \mathrm{Kcal}$ and bitter PTC intensity $(r=-0.579, P=0.008)$.

In our hands, the administration of $\mathrm{HCl}$ quinine in healthy subjects was able to significantly reduce calorie intake in an ad libitum food intake test. In particular, the subjects ingested about $15 \%$ less calories when compared to placebo, and this occurred without a significant change in meal duration. This result is in agreement with previously published data showing that quinine per se strongly reduces food intake in rats, independently of its aversive taste. $^{27,28}$ In addition, we found that the quinine-mediated reduction of food intake is associated to the individual ability to percept PTC, since a significantly lower amount of calories was observed in "tasters" than in "non-tasters" subjects.

We used quinine, an anti-malarial drug extracted from the bark of the cinchona tree, able to trigger bitter taste by the activation of several members of T2R family receptors. ${ }^{29}$ The drug was administered by an acid-resistant capsule for 2 main reasons: (1) in order to prevent the activation of the taste receptors of the oral cavity and (2) to prevent the release of ghrelin, produced by the $\mathrm{X} / \mathrm{A}$-like cells of the oxyntic glands of the stomach and to allow its release into the duodenum where CCK-releasing EECs are located. $^{19}$

The role of bitter taste in the control of digestive functions is controversial: bitter compounds are naturally unpleasant. From a classical point of view, the bitter taste evolved in order to refuse potentially toxic compounds, such as plant alkaloids or microbial toxins. However, bitter compounds are also used to stimulate appetite or digestion in several parts of the world. For example, the habit of drinking aperitif before a meal is justified by the belief that the bitter taste stimulates appetite and increases gastric secretion.

Gustatory signals likely play a role in the cephalic phase of food intake to prepare the digestive tract to receive food. ${ }^{30}$ However, previous studies have shown that the activation of intestinal $\mathrm{T} 2 \mathrm{R}$ results in the release of gut peptides, suggesting a role in the post-ingestion phase of food intake. ${ }^{18,19,31}$ In particular, the release of ghrelin from gastric EECs may explain, at least partially, that bitter compounds could increase appetite feeling.

The process that limits calorie intake is the result of a coordinated series of neural and humoral signals that originate from the gut. In particular, hormonal signaling is strongly influenced by intra-luminal chemicals (lipid, carbohydrates, and amino acids). ${ }^{32}$ According to our preliminary hypothesis, quinine failed to affect 
ghrelin release while significant postprandial CCK increase occurred. These data could explain, at least partially, the lower calorie intake in comparison to placebo. To the best of our knowledge, this is the first report indicating that quinine, a T2R agonist, is able to modify postprandial CCK-release in humans.

Taking into account that the gastric motility may affect food intake, ${ }^{33}$ we studied in a subset of volunteers the effect of quinine on gastric emptying rate. Our results failed to find any significant change of quinine compared to placebo, further suggesting that the reduced calorie intake is independent of gastric motility. Although bitter compounds in rats were able to delay gastric emptying, our result is in agreement with a previous study showing that quinine did not affect the rate of gastric emptying in humans. $^{34,35}$

The sensitivity to bitter compounds is genetically grounded and individuals can be classified as "tasters" or "non-tasters" because of their ability to recognize PTC. Chang et al ${ }^{36}$ have demonstrated a positive relationship between PTC/PROP taster status and oral taste sensitivity to sucrose or quinine. To verify that both oral and gut taste mechanisms are comparable, we also screened the oral taste status of PTC in each subject. We found that the effects of quinine on calorie intake affected only subjects who were able to discriminate PTC, but not PTC non-tasters. However, only a non-significant trend in CCK increase was observed after the administration of quinine in PTC tasters.

Our results suggest that quinine-mediated CCK release is likely unable per se to explain the observed effects on food intake and other mechanisms could be involved in the food intake reduction. To date, it is known that bitter stimuli trigger the release of gut hormones in EECs through a mechanism appearing to involve T2Rs, $\alpha$-subunits of the $G$ protein gustducin, phospholipase and $\mathrm{Ca}^{2+}$ influx. ${ }^{18}$ Given the complexity of bitter stimuli transduction pathways in GI cells, we can speculate that other mechanisms (ie, via gustducin, calcium or phospholipase) may play a role in quinine-related effects on food intake, activating neural reflexes and/or acting in a paracrine or endocrine manner.

Various studies have tried to elucidate the physiological role of gut taste receptors in humans. Gerspach et $\mathrm{al}^{37}$ demonstrated that lactisole, a T1R1/T1R3 (sweet) antagonist, induced a significant reduction in GLP-1 and PYY but not CCK secretion, in response to intragastric and intraduodenal glucose administration. Our study demonstrates, for the first time, that bitter taste receptors are also involved in the physiological mechanisms that control appetite in humans. Therefore, while the role of the T2Rs in the oral cavity would prevent the intake of hazardous chem- icals, the bitter taste receptors in the GI tract may act as a second level mechanism which is able to further limit the intake of potentially toxic bitter chemicals. Jeon et $\mathrm{al}^{31}$ showed that T2R signaling stimulates the secretion of CCK from EECs and induces the expression of ATP-binding cassette B1, a transporter expressed on the apical membrane of intestinal epithelial cells able to limit absorption of toxic substrates, both in Caco-2 cells and mouse intestine, through a CCK-dependent mechanism.

Summarizing, we showed that the intra-luminal release of quinine, a bitter taste receptor agonist, significantly reduces the calorie intake in an ad libitum test in healthy subjects, by a mechanisms likely involving CCK. Furthermore, the reduced calorie intake was positively associated with bitter PTC status. Our results suggest that $\mathrm{T} 2 \mathrm{R}$ signaling in the human gut may have a role in energy intake and appetite control, likely through the release of gut hormones. However, further studies are needed to elucidate the ability of bitter taste receptors to control food intake. In particular, it could be of extreme interest to test whether the stimulation of bitter receptors is able to limit calorie intake, and whether bitter compounds, other than quinine, are able to exert similar effects. In conclusion, if our hypothesis will be confirmed, we can speculate that the modulation of T2R activity could turn out to be a novel therapeutic approach to over-nutritional diseases and obesity.

\section{Acknowledgements}

The authors would like to express gratitude to Eleonora Effice for her help in the administration of the capsule to volunteers and Rosanna Scala for her help with the preparation of the manuscript.

\section{References}

1. Chaudhari N, Roper SD. The cell biology of taste. J Cell Biol 2010; 190:285-296.

2. Lindemann B. Receptors and transduction in taste. Nature 2001; 413:219-225

3. Chandrashekar J, Hoon MA, Ryba NJ, Zuker CS. The receptors and cells for mammalian taste. Nature 2006;444:288-294.

4. Kim UK, Drayna D. Genetics of individual differences in bitter taste perception: lessons from the PTC gene. Clin Genet 2005;67:275-280.

5. Janssen S, Depoortere I. Nutrient sensing in the gut: new roads to therapeutics? Trends Endocrinol Metab 2013;24:92-100.

6. Rozengurt E, Sternini C. Taste receptor signaling in the mammalian gut. Curr Opin Pharmacol 2007;7:557-562.

7. Wu SV, Rozengurt N, Yang M, Young SH, Sinnett-Smith J, 
Rozengurt E. Expression of bitter taste receptors of the T2R family in the gastrointestinal tract and enteroendocrine STC-1 cells. Proc Natl Acad Sci USA 2002;99:2392-2397.

8. Rozengurt N, Wu SV, Chen MC, Huang C, Sternini C, Rozengurt E. Colocalization of the alpha-subunit of gustducin with PYY and GLP-1 in L cells of human colon. Am J Physiol Gastrointest Liver Physiol 2006;291:G792-G802.

9. Jeon TI, Zhu B, Larson JL, Osborne TF. SREBP-2 regulates gut peptide secretion through intestinal bitter taste receptor signaling in mice. J Clin Invest 2008;118:3693-3700.

10. Sternini C, Anselmi L, Rozengurt E. Enteroendocrine cells: a site of 'taste' in gastrointestinal chemosensing. Curr Opin Endocrinol Diabetes Obes 2008;15:73-78.

11. Wren AM, Bloom SR. Gut hormones and appetite control. Gastroenterology 2007;132:2116-2130.

12. Cummings DE, Purnell JQ, Frayo RS, Schmidova K, Wisse BE, Weigle DS. A preprandial rise in plasma ghrelin levels suggests a role in meal initiation in humans. Diabetes 2001;50:1714-1719.

13. Stengel A, Taché Y. Yin and yang - the gastric X/A-like cell as possible dual regulator of food intake. J Neurogastroenterol Motil 2012; 18:138-149.

14. Kissileff HR, Pi-Sunyer FX, Thornton J, Smith GP. C-terminal octapeptide of cholecystokinin decreases food intake in man. Am J Clin Nutr 1981;34:154-160.

15. McLaughlin J, Grazia Lucà M, Jones MN, D'Amato M, Dockray GJ, Thompson DG. Fatty acid chain length determines cholecystokinin secretion and effect on human gastric motility. Gastroenterology 1999;116:46-53.

16. Buchan AM, Polak JM, Solcia E, Capella C, Hudson D, Pearse AG. Electron immunohistochemical evidence for the human intestinal I cell as the source of CCK. Gut 1978;19:403-407.

17. Baldwin BA, Parrott RF, Ebenezer IS. Food for thought: a critique on the hypothesis that endogenous cholecystokinin acts as a physiological satiety factor. Prog Neurobiol 1998;55:477-507.

18. Chen MC, Wu SV, Reeve JR Jr, Rozengurt E. Bitter stimuli induce $\mathrm{Ca}^{2+}$ signaling and CCK release in enteroendocrine STC-1 cells: role of L-type voltage-sensitive $\mathrm{Ca}^{2+}$ channels. Am J Physiol Cell Physiol 2006;291:C726-C739.

19. Janssen S, Laermans J, Verhulst PJ, Thijs T, Tack J, Depoortere I. Bitter taste receptors and alpha-gustducin regulate the secretion of ghrelin with functional effects on food intake and gastric emptying. Proc Natl Acad Sci USA 2011;108:2094-2099.

20. Fireman Z, Kopelman Y, Friedman S, et al. Age and indication for referral to capsule endoscopy significantly affect small bowel transit times: the given database. Dig Dis Sci 2007;52:2884-2887.

21. Ewe K, Press AG, Bollen S, Schuhn I. Gastric emptying of indigestible tablets in relation to composition and time of ingestion of meals studied by metal detector. Dig Dis Sci 1991;36:146-152.

22. Cuomo R, Savarese MF, Sarnelli G, et al. The role of a pre-load beverage on gastric volume and food intake: comparison between non- caloric carbonated and non-carbonated beverage. Nutr J 2011;10:114.

23. Cuomo R, Sarnelli G, Grasso R, et al. Functional dyspepsia symptoms, gastric emptying and satiety provocative test: analysis of relationships. Scand J Gastroenterol 2001;36:1030-1036.

24. Stubbs RJ, Hughes DA, Johnstone AM, et al. The use of visual analogue scales to assess motivation to eat in human subjects: a review of their reliability and validity with an evaluation of new hand-held computerized systems for temporal tracking of appetite ratings. Br J Nutr 2000;84:405-415.

25. Hu ML, Rayner CK, Wu KL, et al. Effect of ginger on gastric motility and symptoms of functional dyspepsia. World J Gastroenterol 2011;17:105-110

26. Chen CY, Lu CL, Chang FY, et al. Delayed liquid gastric emptying in patients with hepatocellular carcinoma. Am J Gastroenterol 2000; 95:3230-3237.

27. Ishii Y, Blundell JE, Halford JC, Rodgers RJ. Palatability, food intake and the behavioural satiety sequence in male rats. Physiol Behav 2003;80:37-47.

28. Heybach JP, Boyle PC. Dietary quinine reduces body weight and food intake independent of aversive taste. Physiol Behav 1982;29: 1171-1173.

29. Wiener A, Shudler M, Levit A, Niv MY. BitterDB: a database of bitter compounds. Nucleic Acids Res 2012;40:D413-D419.

30. Cuomo R, D'Alessandro A, Andreozzi P, Vozzella L, Sarnelli G. Gastrointestinal regulation of food intake: do gut motility, enteric nerves and entero-hormones play together? Minerva Endocrinol 2011;36:281-293.

31. Jeon TI, Seo YK, Osborne TF. Gut bitter taste receptor signalling induces $\mathrm{ABCB} 1$ through a mechanism involving CCK. Biochem J 2011;438:33-37.

32. Cummings DE, Overduin J. Gastrointestinal regulation of food intake. J Clin Invest 2007;117:13-23.

33. Janssen P, Vanden Berghe P, Verschueren S, Lehmann A, Depoortere I, Tack J. Review article: the role of gastric motility in the control of food intake. Aliment Pharmacol Ther 2011;33:880-894.

34. Glendinning JI, Yiin YM, Ackroff K, Sclafani A. Intragastric infusion of denatonium conditions flavor aversions and delays gastric emptying in rodents. Physiol Behav 2008;93:757-765.

35. Little TJ, Gupta N, Case RM, Thompson DG, McLaughlin JT. Sweetness and bitterness taste of meals per se does not mediate gastric emptying in humans. Am J Physiol Regul Integr Comp Physiol 2009;297:R632-R639.

36. Chang WI, Chung JW, Kim YK, Chung SC, Kho HS. The relationship between phenylthiocarbamide (PTC) and 6-n-propylthiouracil (PROP) taster status and taste thresholds for sucrose and quinine. Arch Oral Biol 2006;51:427-432.

37. Gerspach AC, Steinert RE, Schōnenberger L, Graber-Maier A, Beglinger $\mathrm{C}$. The role of the gut sweet taste receptor in regulating GLP-1, PYY, and CCK release in humans. Am J Physiol Endocrinol Metab 2011;301:E317-E325. 